\title{
Studies on Farm Crop Response to Plant Nutrients in Predominant Cropping Systems and their Impact on Crop - Livestock - Human Continuum under Central Vidharbha Zone of Maharashtra
}

\author{
Y. D. Charjan ${ }^{1 *}$, R. S. Wankhade ${ }^{2}$ and M. R. Deshmukh ${ }^{3}$ \\ ${ }^{1}$ Experiments on Cultivators Field (OFR), Katol, Dist. Nagpur, India \\ ${ }^{2}$ Department of Agronomy, Dr. Panjabrao Deshmukh Krishi Vidyapeeth, Akola, India \\ ${ }^{3}$ Agriculture Research Station, Dr. Panjabrao Deshmukh Krishi Vidyapeeth, Achalpur Dist. \\ Amravati-Mahrashtra, India \\ *Corresponding author
}

\section{A B S T R A C T}

\begin{tabular}{|l|}
\hline Ke y w o r d s \\
On-farm \\
experiment, \\
Economics, \\
Cropping systems, \\
Central Vidarbha \\
Zone
\end{tabular}

\begin{abstract}
A experiment was carried out on twenty four farmer's fields to study the response of major nutrients NPKS on soybean-wheat, soybean-chickpea and cotton-fallow crops sequences in Central Vidarbha Zone (Nagpur) Mahrashtra during the year 2018-19. A set of eight treatments comprises of no NPK, $100 \% \mathrm{~N}, 100 \% \mathrm{~N}+100 \% \mathrm{P}, 100 \% \mathrm{~N}+100 \% \mathrm{~K}$, $100 \% \mathrm{~N}+100 \% \mathrm{P}+100 \% \mathrm{~K}, 100 \% \mathrm{~N}+100 \% \mathrm{P}+100 \% \mathrm{~K}+100 \%$ Sulphur, use of organic manure / bio-fertilizers and farmers practice after categorization in initial similar factors by $\mathrm{R}$ statistical method analysis. Result indicated that application of recommended NPK + Sulphur recorded significantly higher yields in soybean $\left(1302 \mathrm{~kg} \mathrm{ha}^{-1}\right)$ - wheat $\left(2042.69 \mathrm{~kg} \mathrm{ha}^{-1}\right)$, soybean $\left(1464.03 \mathrm{~kg} \mathrm{ha}^{-1}\right)$ - chickpea $\left(1654.99 \mathrm{~kg} \mathrm{ha}^{-1}\right)$ and cotton $\left(1889.35 \mathrm{~kg} \mathrm{ha}^{-1}\right)$ crop, respectively. Similarly, the total increase in monitory returns by 10 , 13 and 10 percent and net returns of Rs. $88645 \mathrm{ha}^{-1}, 116358 \mathrm{ha}^{-1}$ and $100135 \mathrm{ha}^{-1}$ under soybean-wheat, soybean - chickpea and cotton - fallow sequential cropping system, respectively.
\end{abstract}

\section{Introduction}

The Central Vidarbha Zone comprises of Yavatmal, Nagpur, Wardha, and part of Chandrapur districts. The Central Vidarbha Zone is the VII ${ }^{\text {th }}$ Agro Climatic zone of Maharashtra State having assured rainfall zone. This tract has hot summer, moderate winter and rainy season which receive 950 to $1250 \mathrm{~mm}$ rainfall in 60 to 70 rainy days. Soils are derived from basalt rock, black in color and having varying in depth. Vertisols, Inceptisols and Entisols are the dominant soil orders occurring in the zone. Soil type in these districts having deep black (43.4\%), medium deep black (13.8\%) and shallow soils (42.7\%) having with an area of 427.9, 136.4 and 421.5 (area 000 ha) hectare, respectively. Main agronomical crops of this zone are cotton, soybean, sorghum, pigeon 
pea in kharif and wheat and gram in rabi season. Nagpur mandarin and vegetable crops viz., brinjal, tomato grown in Nagpur district.

During 2018-19 the experiments were conducted in two blocks of Nagpur district. One is high productive block of Katol and second low productive block of Narkhed. Major farming system of the district is crop + livestock. Soybean-wheat, Soybean-Chickpea and Cotton-fallow cropping system, a lifeline for the majority of the population in Central Vidarbha Zone is under stress, due to the imbalanced and indiscriminate use of fertilizers.

Therefore, we conducted an on-farm study at two locations (Katol and Narkhed in Nagpur District) covering Twenty Four Farmers to judge the response of NPK and $S$ in Central Vidarbha Zone (Nagpur) Mahrashtra.

\section{Materials and Methods}

Data employed in this study were taken from on-farm experiments conducted with Soybean and wheat, Soybean and Chickpea and Cotton-Follow between 2018 to 2019 in the Indian districts of Nagpur in the Maharashtra state, under the umbrella of the All India Coordinated Research Project (AICRP) on Integrated Farming systems (IFS) by the Indian Council of Agricultural Research (ICAR). A experiment was carried out on farmers field to study the response of major nutrients NPKS on soybean-wheat (06 farmers), soybean-chickpea (06 farmers) and cotton-fallow(12 farmers) in crops sequences on twenty four farmer's fields in Central Vidarbha Zone (Nagpur) Mahrashtra during the year 2018-19. Treatments comprises viz., $\mathrm{T}_{1}-$ No NPK, $\mathrm{T}_{2}-100 \% \mathrm{~N}, \mathrm{~T}_{3}-100 \% \mathrm{~N}+$ $100 \% \mathrm{P}, \mathrm{T}_{4}-100 \% \mathrm{~N}+100 \% \mathrm{~K}, \mathrm{~T}_{5}-100$ $\% \mathrm{~N}+100 \% \mathrm{P}+100 \% \mathrm{~K}, \mathrm{~T}_{6}-100 \% \mathrm{~N}+$ $100 \% \mathrm{P}+100 \% \mathrm{~K}+100 \%$ Sulphur, $\mathrm{T}_{7-}$ Use of organic manure / Bio-fertilizers and
$\mathrm{T}_{8^{-}}$Farmers practice, respectively with six replications in Soybean - Wheat, six in Soybean - Chickpea and twelve in Cotton fallow sequence cropping systems after categorization in initial similar factors by $\mathrm{R}$ statistical method analysis. Similar farmer taken into the cluster for study. Information of farmers collected and identical farmers were chosen. The levels of applied nutrients were used as per the standard recommendation of the University.

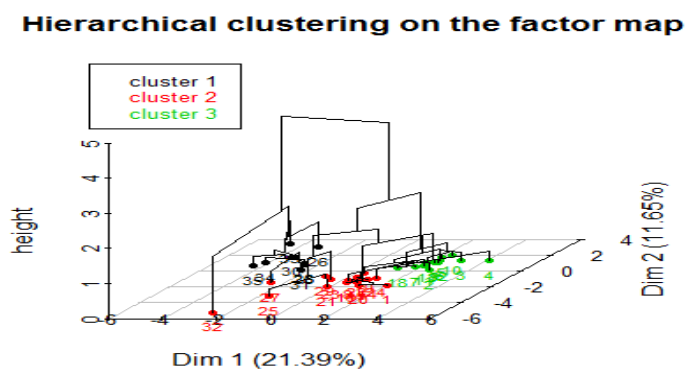

During Kharif 2018, Nagpur district received total $902.6 \mathrm{~mm}$ rainfall in 55 rainy days, $20.79 \%$ less with reduced number of rainy days than normal. The total rainfall received and number of rainy days in operational block i.e. Narkhed $571.4 \mathrm{~mm}$ in 36 rainy days and in Katol block $581.7 \mathrm{~mm}$ in 40 rainy days which was $44 \%$ and $40 \%$ less than normal, respectively. During the crop growth stages particularly at the time of flowering to pod development stage of soybean crop, it was affected due to less rainfall. Also early withdrawal of mansoon resulted into low yield of long duration crop like cotton and pigeon pea.

The meager infestation of whitefly and spodoptera recorded on soybean crop which was controlled by spraying of recommended insecticides during the crop growing period. This year, some pockets of cotton were infested by boll worms which resulted into low seed cotton yield. 


\section{Results and Discussion}

\section{Soybean - wheat system}

The yield benefit due to treatments is given in Table-1 and in Figure 1. The data indicated that the yields of soybean were increased significantly due to application of all treatments over control and Soybean yield $1302 \mathrm{~kg} \mathrm{ha}^{-1}$ was obtained by application of recommended dose of NPK + Sulphur which was significantly superior over application of all treatments. The yields obtained from wheat were influenced significantly due to all treatments over control. Application of NPK with sulphur (2042.69 $\mathrm{kg} / \mathrm{ha}) \quad$ was significantly superior over all treatments. The highest net return under Soybean - Wheat system was recorded Rs $88645 \mathrm{ha}^{-1}$ due to application of NPK with Sulphur and lowest Rs 34887 ha $^{-1}$ with control treatment. Similar observations were reported by Bhattacharyya et al., (2008).

Table.1 Influence of treatments on grain yield ( $\mathrm{kg} / \mathrm{ha})$, economics (Rs/ha) and nutrient response $(\mathrm{kg} / \mathrm{kg} \& \mathrm{Rs} / \mathrm{re})$ of crops for soybean - wheat cropping system

\begin{tabular}{|l|c|c|c|c|c|}
\hline \multicolumn{1}{|c|}{ Treatments } & $\begin{array}{c}\text { Kharif } \\
\text { (Soybean) } \\
\text { Kg/ha }\end{array}$ & $\begin{array}{c}\text { Rabi } \\
\text { (Wheat) } \\
\text { Kg/ha }\end{array}$ & SEY & $\begin{array}{c}\text { SYS cost of } \\
\text { cultivation }\end{array}$ & $\begin{array}{c}\text { System net } \\
\text { returns }\end{array}$ \\
\cline { 2 - 6 } & Grain & Grain & Grain & Rs/ha & Rs/ha \\
\hline Control & 445.57 & 896.93 & 1090.24 & 31025 & 34887 \\
\hline N & 596.03 & 1070.53 & 1365.47 & 32634 & 43695 \\
\hline NP & 891.15 & 1498.75 & 1968.37 & 34218 & 62987 \\
\hline NK & 769.63 & 1232.56 & 1655.53 & 33113 & 52976 \\
\hline NPK & 1139.97 & 1637.63 & 2317.02 & 36344 & 74144 \\
\hline NPK + S & 1302.00 & 2042.69 & 2770.19 & 38869 & 88645 \\
\hline Organic & 758.05 & 1267.28 & 1668.91 & 33835 & 53405 \\
\hline FP & 688.61 & 1001.09 & 1408.15 & 29547 & 45060 \\
\hline CD $(\mathbf{P = 0 . 0 5 )}$ & 111.93 & 187.11 & 192.13 & - & - \\
\hline CV $(\mathbf{\%})$ & 11.64 & 12.05 & 9.25 & - & - \\
\hline
\end{tabular}

Table.2 Influence of treatments on grain yield ( $\mathrm{kg} / \mathrm{ha})$, economics (Rs/ha) \& nutrient response $(\mathrm{kg} / \mathrm{kg} \& \mathrm{Rs} / \mathrm{re})$ of crops for soybean- chickpea system

\begin{tabular}{|c|c|c|c|c|c|}
\hline Treatments & $\begin{array}{c}\text { Kharif } \\
\text { (Soybean) Kg/ha }\end{array}$ & $\begin{array}{c}\text { Rabi } \\
\text { (Chickpea) Kg/ha }\end{array}$ & $\begin{array}{l}\text { SEY } \\
\text { Kg/ha }\end{array}$ & $\begin{array}{l}\text { SYS cost of } \\
\text { cultivation }\end{array}$ & $\begin{array}{l}\text { System net } \\
\text { returns }\end{array}$ \\
\hline & Grain & Grain & Grain & Rs/ha & Rs/ha \\
\hline Control & 567.09 & 694.40 & 1478.49 & 28920 & 47311 \\
\hline $\mathbf{N}$ & 729.12 & 908.51 & 1921.54 & 30290 & 61489 \\
\hline NP & 1111.04 & 1249.92 & 2751.56 & 31958 & 88049 \\
\hline NK & 1111.04 & 1058.96 & 2500.93 & 32519 & 80029 \\
\hline NPK & 1232.56 & 1406.16 & 3078.15 & 34616 & 98500 \\
\hline $\mathrm{NPK}+\mathrm{S}$ & 1464.03 & 1654.99 & 3636.20 & 36360 & 116358 \\
\hline Organic & 908.51 & 1151.55 & 2419.91 & 30538 & 77437 \\
\hline FP & 792.77 & 810.13 & 1856.07 & 28374 & 59394 \\
\hline $\mathrm{CD}(\mathrm{P}=\mathbf{0 . 0 5})$ & 153.03 & 180.62 & 305.26 & - & - \\
\hline CV (\%) & 13.26 & 13.86 & 10.66 & - & - \\
\hline
\end{tabular}


Table.3 Influence of treatments on seed cotton yield ( $\mathrm{kg} / \mathrm{ha})$, economics (Rs/ha) \& nutrient response $(\mathrm{kg} / \mathrm{kg} \& \mathrm{Rs} / \mathrm{re})$ of crops for cotton- fallow system

\begin{tabular}{|l|c|c|c|c|c|}
\hline \multirow{2}{*}{ Treatments } & $\begin{array}{c}\text { Kharif (Cotton) } \\
\text { Kg/ha }\end{array}$ & $\begin{array}{c}\text { Rabi (Fall.) } \\
\text { Kg/ha }\end{array}$ & $\begin{array}{c}\text { SEY } \\
\text { Kg/ha }\end{array}$ & $\begin{array}{c}\text { SYS cost of } \\
\text { cultivation }\end{array}$ & $\begin{array}{c}\text { System net } \\
\text { returns }\end{array}$ \\
\cline { 2 - 6 } Seed cotton & Grain & Grain & Rs/ha & Rs/ha \\
\hline Control & 717.55 & - & - & 19162 & 38029 \\
\hline N & 917.15 & - & - & 20175 & 48610 \\
\hline NP & 1571.08 & - & - & 22171 & 83267 \\
\hline NK & 1336.72 & - & - & 19572 & 70846 \\
\hline NPK & 1744.68 & - & - & 25034 & 92468 \\
\hline NPK + S & 1889.35 & - & - & 26338 & 100135 \\
\hline Organic & 1102.36 & - & - & 20542 & 58425 \\
\hline FP & 928.76 & - & - & 18702 & 49224 \\
\hline CD $(\mathbf{P = 0 . 0 5 )}$ & 156.54 & - & - & - & - \\
\hline CV $(\%)$ & 5.26 & - & - & - & - \\
\hline
\end{tabular}

Fig.1

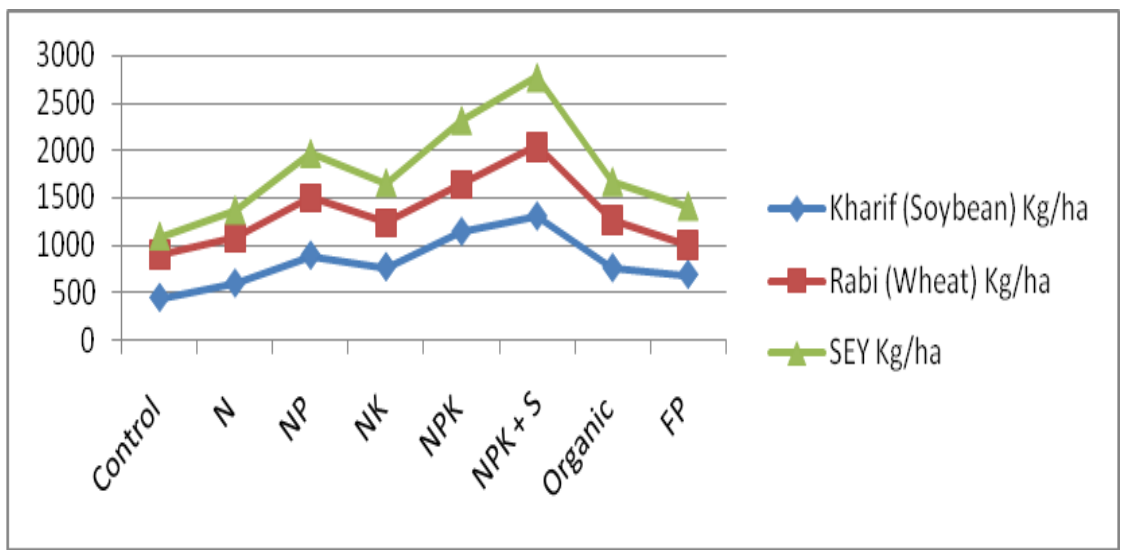

Fig.2

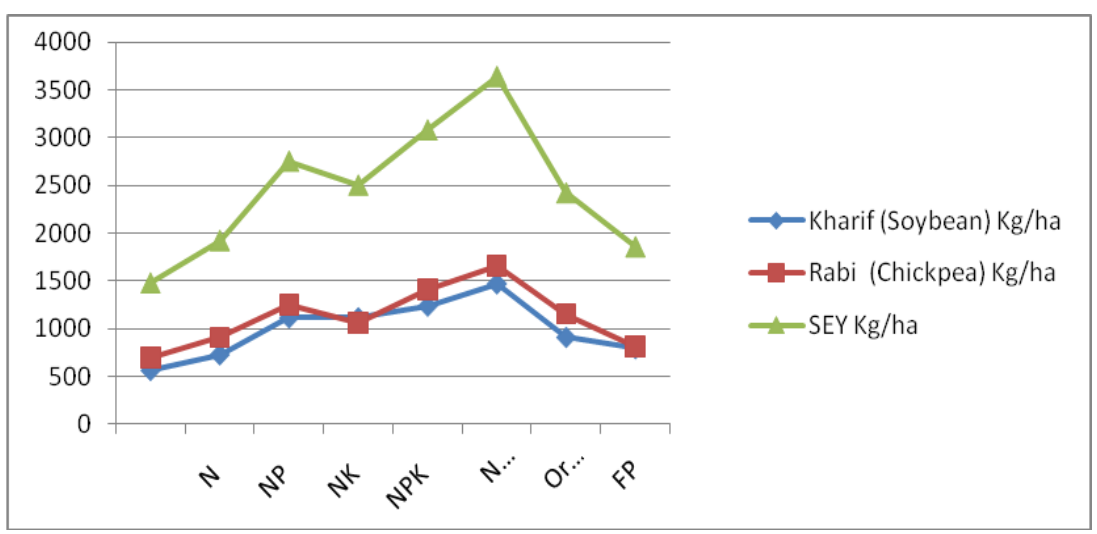


Fig.3

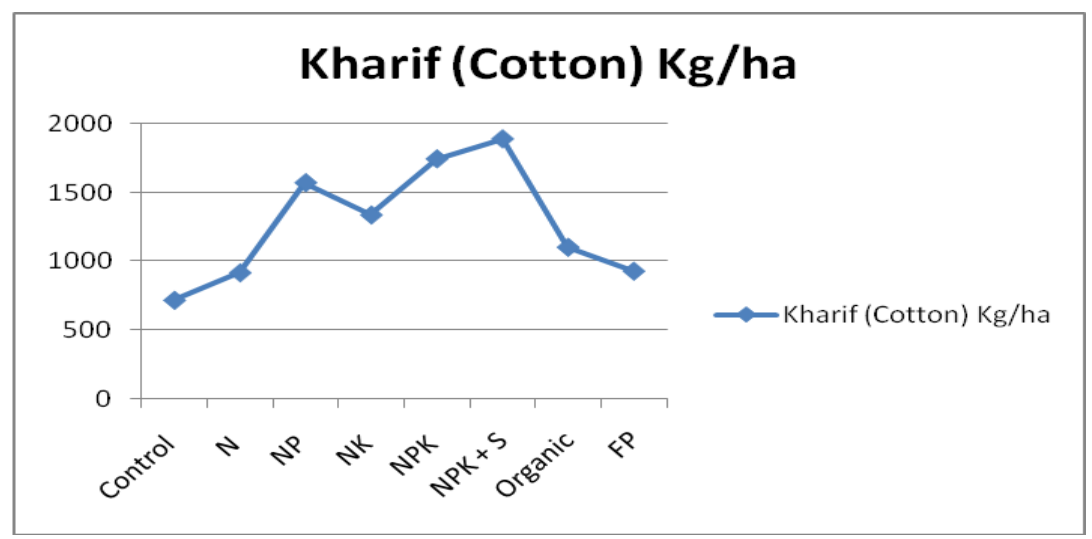

\section{Soybean-chickpea system}

The yields obtain due to the different treatments is given in Table 2 and Figure 2. The data indicated that the yield of Soybean was increased significantly due to application of N, NP, NK over control. Application of recommended dose of NPK + Sulphur increased the yields i.e. $1464.03 \mathrm{kgha}^{-1}$ significantly superior over all treatments. The yields of Chickpea were influenced significantly due to all treatments over control. Application of NPK with Sulphur yielded (1654.99 $\left.\mathrm{kgha}^{-1}\right)$ significantly superior over all other treatments in chickpea. Highest System yield in soybean - chick pea system was noticed by application of NPK $+\mathrm{S}$ i.e. $3636.20 \mathrm{~kg} \mathrm{ha}^{-1}$ and more net returns 116358 Rs. /ha were achieved by application of NPK $+\mathrm{S}$ over farmers practice. Findings in lines with Singh et al., (2008).

\section{Cotton-fallow system}

The yields obtain due to the different treatments is given in Table 3 and Figure 3. The data indicated that the yield of cotton was increased significantly due to application of $\mathrm{N}$, NP, NK over control. Application of recommended dose of NPK + Sulphur increased the yields i.e. $1889.35 \mathrm{kgha}^{-1}$ significantly superior over application of $\mathrm{N}$,
NP and NK However it was at par with application of NPK. Highest System net returns $100135 \mathrm{Rs}$. /ha was achieved by application of NPK $+\mathrm{S}$ over farmers practice. Similar results were recorded by Srinivasulu and Hema (2007).

In conclusion the result indicated that application of recommended NPK + Sulphur recorded significantly higher yields in soybean $\left(1302 \mathrm{~kg} \mathrm{ha}^{-1}\right)$ - wheat $(2042.69 \mathrm{~kg}$ $\left.\mathrm{ha}^{-1}\right)$, soybean $\left(1464.03 \mathrm{~kg} \mathrm{ha}^{-1}\right)$ - chickpea $\left(1654.99 \mathrm{~kg} \mathrm{ha}^{-1}\right)$ and cotton $\left(1889.35 \mathrm{~kg} \mathrm{ha}^{-1}\right)$ crop, respectively. Similarly, the total increase in monitory returns by 10,13 and 10 percent and net returns of Rs. $88645 \mathrm{ha}^{-1}$, $116358 \mathrm{ha}^{-1}$ and $100135 \mathrm{ha}^{-1}$ under soybeanwheat, soybean - chickpea and cotton fallow sequential cropping system, respectively.

\section{References}

Bhattacharyya R, Kundu S, Prakash V, and Gupta HS (2008) Sustainability under combined application of mineral and organic fertilizers in a rainfed soybeanwheat system of the Indian Himalayas. Eur J Agron28:33-46.

R Studio 2019. https:// www.rstudio.com

Singh A, Saha J, Gosh P (2008) Effect of nutrient management practices on 
soybean (Glycine max)-chickpea (Cicer arietinum) cropping systems for improving seed yield, quality and soil biological health under rainfed condition. Indian Journal of Agriculture Science 78(6): 485-489. integrated nutrient management in enhancing and sustaining cotton (Gossypium hirsutum L.) productivity. Journal of Cotton Research and Development, 21(2): 218-221.

Srinivasulu, K. and Hema, K., 2007. Effect of

\section{How to cite this article:}

Charjan, Y. D., R. S. Wankhade and Deshmukh, M. R. 2020. Studies on Farm Crop Response to Plant Nutrients in Predominant Cropping Systems and their Impact on Crop - Livestock Human Continuum under Central Vidharbha Zone of Maharashtra. Int.J.Curr.Microbiol.App.Sci. 9(12): 2345-2350. doi: https://doi.org/10.20546/ijcmas.2020.912.278 